\title{
Research Article: Mechanized system rice intensification (MSRI) is boon to farmers to save money and time in rice cultivation in Vizianagaram district of North Coastal Zone of Andhra Pradesh
}

Article Chronicle:

Received :

23.04.2020;

Revised:

04.06.2020;

Accepted :

06.07.2020

\section{KEY WoRds :}

Mechanized system rice intensification (MSRI), Cono weeder, OFTs, Yield, Yield attributes, B:C ratio

Author for correspondence :

M.M.V. Srinivasa Rao Department of Agronomy, District Agricultural

Advisory and Transfer of Technology Centres (AN.G.RA.U.), Gajulurega, Vizianagram (A.P.) India Email: mmvsrangrau@ gmail.com

See end of the article for authors' affiliations
SUMMARY : Paddy is major predominant crop during Kharif in Vizianagaram district of Andhra Pradesh, cultivated in an area of $112353 \mathrm{ha}$, out of total cropped area of 117608 ha with productivity of $2524 \mathrm{~kg} /$ ha. Farmers grow crop by adopting traditional method of paddy cultivation, use more seed rate, close spacing, late transplanting with over aged seedlings common phenomenon due to erotic rainfall climate change. Scarcity of labour and escalation in labour wages, reduction in labour efficiency are leading to low net returns. In this context DAATT Centre, Vizianagaram district of ANGRAU, in collaboration with Department of Agriculture, Vizianagaram has introduced "Mechanized System Rice Intensification (MSRI). Mechanized system rice intensification (MSRI) is boon to farmers to save money and time. DAATT Centre, Vizianagaram has organized on farm trials (OFTs) in farmer fields in two seasons Kharif, 2015 and Kharif, 2016. MSRI technology in paddy recorded 20.76 per cent yield over normal transplanting method of paddy cultivation during both Kharif seasons. The results from the study showed that the farmers realized the Rs. 15038 additional net income due to increased grain yield by 20.76 per cent with reduction of cost of cultivation by Rs.1150, it could be attributed to reduction in manual labour of 3 man labour and 21 women labour per ha and also increase in yield attributes and yield.

How to cite this article : Srinivasa Rao, M.M.V., Roy, G.S. and Lakshmana, K. (2020). Mechanized system rice intensification (MSRI) is boon to farmers to save money and time in rice cultivation in Vizianagaram district of North Coastal Zone of Andhra Pradesh. Agric. Update, 15(3): 162-166; DOI : 10.15740/HAS/AU/15.3/162-166. Copyright@ 2020: Hind Agri-Horticultural Society. 